\title{
Digital Topelius är modernare än vi trott
}

\section{Fullständig utgåva öppnar nya perspektiv}

Zacharias Topelius Skrifter (ZTS) är en fritt tillgänglig digital utgåva som utges av Svenska litteratursällskapet i Finland, på adressen topelius.fi - För första gången kommer Topelius hela författarskap, både tryckt och otryckt material, att finnas tillgängligt i digital och sökbar form med varianter, manuskript, faksimil, kontextualiserande inledningar, kommentarer och ordforklaringar.

Om två år firar vi hundraårsjubileet av Finlands självständighet och året därpå har det gått tvåhundra år sedan Zacharias Topelius (1818-1898) föddes. De två jubileerna griper in i varandra, eftersom man knappast kan tänka sig framväxten av nationen Finland utan författaren och samhällspåverkaren Topelius verksamhet.

Märkesåren aktualiserar frågor om den finska identiteten, om idéhistorien kring nationsbygget och om verk och skeenden som har format den nationella självuppfattningen. Utan tillgång till Topelius verk och utan kunskap om dem är det betydligt svårare att förstå utvecklingen i Finland på 1800-talet. Topelius var i många avseenden modern för sin tid, till och med radikal. Han tog ställning i samhälleliga frågor, det gällde till exempel kvinnors utbildning och språkfrågan, där han stod för balans och tolerans och lyfte fram den eftersatta finskan, för att senare försvara svenskan i ett allt mera inflammerat språkklimat. Som populär författare, opinionsbildare, folkbildare, universitetsrektor och föreningsmänniska nådde han ut till alla samhällsskikt under flera generationer. Den digitala utgåvan Zacharias Topelius Skrifter ger en ny och fördjupad bild av hans verksamhet. Utgåvan är historisk-kritisk och den har en mångsidig sökfunktion. Ett omfattande urval av verken utkommer också i tryck.

\section{Bakgrunden}

Initiativet till utgåvan togs 1998, etthundra år efter Topelius död. Minnesåret med alla begivenheter visade på behovet dels av ny forskning, dels av en tillförlitlig utgåva. Topelius Samlade skrifter hade utkommit i rask takt åren efter författarens död. Upplagan, i 34 delar, utkom på Bonniers förlag med delupplaga på Helsingforsförlaget Edlunds 1899_ 1907. Titeln till trots är skrifterna långt $\mathrm{i}$ från fullständiga, de omfattar i huvudsak de skönlitterära verken. Planen på en vetenskaplig utgåva av Topelius verk presenteras i rapporten Z. Topelius jubileumsår 1998 (1999: 39-46). Kommittén för jubileumsåret efterlyste en modern utgåva och efter utredningar, planering och inventering åtog sig Svenska litteratursällskapet i Finland att vara huvudman för utgivningen av Zacharias Topelius Skrifter. Det redaktionella arbetet inleddes 2005, den första 
delen publicerades 2010 och 2015 har sex delar utkommit.' Det vetenskapliga arbetet utförs under ledning av ett redaktionsråd. Manuskripten till utgåvorna, såväl de ederade verken av Topelius som kommentarer och inledande artiklar, granskas internt och blir därpå referee-granskade externt. Redaktionen består av tolv personer. ${ }^{2}$

Utgåvan har fått finansiering av bland annat Undervisnings- och kulturministeriet för att planera och utveckla de digitala resurserna, och av Finska Vetenskaps-Societeten, Finska Kulturfonden och Svenska folkskolans vänner. Svenska kulturfonden ger utgåvan ett betydande stöd. Nationalbiblioteket, Museiverket och Finlands nationalmuseum samt Statens konstmuseum är också viktiga samarbetsparter eftersom de äger Topeliusrelaterat material.

\section{Den digitala utgåvan}

Den digitala utgåvan Zacharias Topelius Skrifter är den första och största i sitt slag i Finland och den kan användas som plattform också för andra vetenskapliga utgåvor. ${ }^{3}$ Strukturen och visningen i den digitala utgåvan är skapade enkom för ZTS, med ambitionen att utgåvan ska vara enkel att använda. För kodningen använder vi XML (eXtensible Markup Language) och den internationella standarden för uppmärkning av texter Tei (Text Encoding Initiative), för att texterna ska vara stabila, möjliga att migrera och mångsidigt sökbara.

I praktiken innebär det här att varje verk $\mathrm{i}$ utgåvan består av en XML-fil med kvalificerad kodning som möjliggör visning av olika slag. Av särskilt intresse $i$ en textkritisk utgåva är den kodning som visar vilka ändringar utgivaren har infört. Kod som markerar personnamn, geografiska namn och verktitlar införs - dessa kopplas till poster i databaser med uppgifter om personerna, orterna och verken och kompletterar kommentarerna. Posterna fungerar som register som är sökbara i sig.

Alla skillnader mellan originalupplagan och andra relevanta tryck under författarens livstid kodas också, för att visa variationen mellan trycken. Dessa skillnader, de så kallade varianterna, identifierar utgåvan numera med hjälp av programvara. Därefter kontrolleras de manuellt, eller snarast okulärt, innan de kodas för visning.

Utöver inledning, lästext, kommentarer och varianter har utgåvan visning av faksimil och av utskrivna manuskript. Faksimilen är digitaliserade $\mathrm{i}$ hög kvalitet och återger grundtexten. För en utgivare innebär en digital utgåva på inget vis mindre arbete än en tryckt. För användarna

\footnotetext{
I Om utgåvan, se Matti Klinge, Pinaatti ja Saint-Simon: Päiväkirjastani 20/3-20l4 (2014) samt Kim Björklund och Petra Söderlund, "Andra generationens elektroniska utgåvor Selma Lagerlöf-arkivet och Zacharias Topelius Skrifter" (20I I: 59-69).

2 Utgåvans redaktionsråd, redaktion och andra medarbetare: http://www.topelius.fi/index.php?docid=9

3 Arbetet med Henry Parlands Skrifter inleddes på Svenska litteratursällskapet i januari 2015 och utgåvan publiceras i sinom tid i samma digitala miljö som Zacharias Topelius Skrifter. Visningen av varianter används i den digitala utgåvan av Grundtvigs verk (Grundtvig Centeret vid Aarhus Universitet). Utgåvan har utvecklat flera digitala verktyg för att underlätta arbetet och de är tillgängliga för utgåvor och andra intresserade.
} 
däremot är den digitala utgåvan ett effektivare arbetsredskap än en traditionell bokutgåva.

Till jubileumsåret 2018 utvecklas en pedagogisk resurs för skolan som utnyttjar den digitala utgåvans möjligheter $\mathrm{i}$ undervisningen. Den är tänkt som en vägledning till vårt kulturarv, som inspiration till att själv tolka texter och förstå språket i äldre tider. Materialet blir ett fritt tillgängligt komplement till existerande läromedel.

För att öka tillgängligheten är användargränssnittet och inledningarna till de olika delarna översatta till finska. En översättning av användargränssnittet till engelska är under arbete.

\section{Framgångsrik författare - utmanande utgivning}

Topelius etablerade sig som en uppskattad författare när hans första samlingar dikter och sagor, Hertiginnan af Finland och bildverket Finland framställdt i teckningar utkom i Finland på 1840- och I850-talen. På 1850-talet började han utge de skönlitterära verken på Albert Bonniers förlag i Stockholm och blev snabbt en framgångsrik marknadsförfattare, som tack vare den större svenska bokmarknaden utkom i flera upplagor. Topelius tidiga diktsamlingar Ljungblommor I-III (I845-1854) utkom på Bonniers i ett band under titeln Sånger (1860), som under Topelius livstid publicerades $\mathrm{i}$ sex upplagor med sammanlagt långt över 20000 exemplar. ${ }^{4}$ Topelius ändrade och bearbetade sina verk, och det har lett till att de olika upplagorna skiljer sig från varandra på mer eller mindre genomgripande sätt. Därför finns det alltså anledning att välja textunderlag för läsning eller forskning med omsorg - mera om det senare.

Topelius författarskap är överväldigande rikt och de olika upplagorna med många ändringar gör utgivningshistorien till en utmaning. Det är särskilt tacksamt att utge ett sådant författarskap digitalt, eftersom mediet gör det möjligt för användarna att på ett tydligt och överskådligt sätt studera Topelius ändringar, från den ena upplagan till den andra. I de tryckta delarna av ZTS förtecknas skillnader i ordval, men inte i stavning eller interpunktion. I den digitala utgåvan visas alla skillnader.

\section{Hur bearbetade Topelius dikterna?}

Topelius använde gärna vintermotiv, genom hela författarskapet. Ett tidigt exempel är vintervisan som börjar "Vind och hvita vågor ..." och är daterad 1843. Den trycktes första gången i Helsingfors Tidningar den I 3 januari 1844 och ingick i Ljungblommor året därpå. ${ }^{5}$ I de här tidiga trycken är det finsknationella anslaget tydligt, vilket talade till en natio-

\footnotetext{
${ }^{4}$ Se Carola Herberts textkritiska redogörelse i Zacharias Topelius, Ljungblommor, utg. Carola Herberts under medverkan av Clas Zilliacus 20I0. http://www.topelius.fi/index. php?p=texts\&bookld= I\#itemld=I_I \&columns=[[|il|,-I],[||t|,-I],[|ko|,-I]] Vänligen observera att länkarna till utgåvan slutar med två hakparenteser.

${ }^{5} \mathrm{Av}$ verk som har utkommit i bokform återges texten i den första bokupplagan som lästext i utgåvan Zacharias Topelius Skrifter.
} 
nellt nymornad publik i Finland. Inte utan orsak har dikten kallats "ett fosterländskt manifest". Här förekommer "Suomis hed och ljung", "gamla runor" och ett trofast finskt hjärta i andra resp. fjärde strofen.

Inför utgivningen i Stockholm 1860 strök Topelius dessa strofer, omarbetade en och skrev två nya som han placerade sist. Han lyfter fram naturintrycken och privatsfären på bekostnad av de nationella markörerna. I den nyskrivna texten finns den pregnanta bilden "Furans skugga vexer / Till en jätte ren. / På dess mörka gren / Hänger månens skifva". Vid omarbetningen har Topelius i en strof ändrat preteritumformerna av verben till presens, vilket bidrar till en stark känsla av närvaro i nuet. De ursprungliga slutverserna låter på följande sätt:

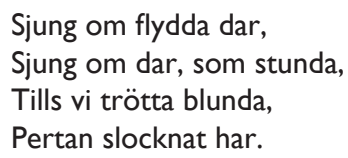

Den något melankoliska och trötta stämningen ersätter Topelius med rader där till och med interpunktionen förmedlar glädjen över den friska vinternaturen:

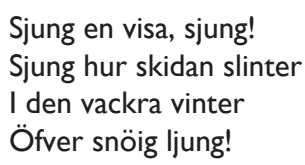

Trots de här omfattande ändringarna daterar Topelius fortfarande dikten I843 i alla tryck från 1845 till 1888. - För en gångs skull verkar han nöjd med resultatet, för i upplagorna 1880 och 1888 är dikten identisk med trycket $1860 .^{6}$

Vid läsningen av en beskrivning som den här försöker forskaren för sitt inre öga se Topelius ändringar, som inte är helt enkla att visualisera. Den uppenbara fördelen med variantvisning i fulltext i en digital utgåva är att alla relevanta textvittnen (i det här fallet de olika trycken) serveras på en bricka och användaren kan i lugn och ro studera skillnaderna mellan dem och göra egna iakttagelser: http://www.topelius.fi/index.php? $p=$ text s\&bookld= I\#itemld=I_I 7\&columns=[[|ih|,-I],[|lt|,-I],[|va|,0],[|va|, I ],[|va |,2],[|va|,3],[|va|,4],[|ko|,- I]]

\section{Prosaverken och versionerna av dem}

Topelius var redaktör för Helsingfors Tidningar 1842-1860 och prosaverken som han skrev under dessa år publicerades nästan utan undantag först som följetonger i tidningen. Det gäller för både Hertiginnan af Finland och Fältskärns berättelser. På I880-talet bearbetade Topelius ett trettiotal följetonger grundligt för utgivning i bokform. De utkom på Bonniers för-

\footnotetext{
${ }^{6}$ Jfr dikten "Lärkröster i maj" där Topelius ändrar texten i tre strofer och stryker en inför upplagan 1860. I upplagorna 1880 och 1888 återställer han dikten som han lät trycka den 1844 och 1845; dateringen 1844 kvarstår i alla upplagor. http://www. topelius.fi/index.php?p=texts\&bookld=I\#itemld=I_I0\&columns=[[|ih|,-I],[|lt|,-I],[|va|, 0],[|va|,I],[|va|,2],[|va|,3],[|va|,4],[|ko|,-I]]
} 
lag under samlingstiteln Vinterqvällar och översattes snabbt till finska. Här har Topelius gjort så stora ändringar att de verk som ingår i Vinterqvällar, under samma titlar som i Helsingfors Tidningar trettio år tidigare, är att betrakta som nya versioner. Ändringarna rör också nu detaljer och formuleringar, men Topelius strukturerar dessutom om, ändrar karaktärer och låter handlingen ta andra vägar. I Zacharias Topelius Skrifter blir både följetongsversionen och den senare versionen i Vinterqvällar utgivna.

Mest ändrade Topelius i Hertiginnan af Finland.' (Se även Pettersson i denna publikation. Red. anm.) Den gick först som följetong i Helsingfors Tidningar vårterminen 1850 , och redan under pågående publicering bytte Topelius koncept och utökade det historiska materialet. Under våren delade han upp följetongen, som utkom i bokform till julen I850, i en historisk del om hattarnas krig I74I-I743 och en del som koncentrerar sig på den så kallade hertiginnan Eva Merthens förhållande till skotten James Keith, som var rysk överbefälhavare i Finland under ockupationen 1742-1743..$^{8}$ | bearbetningen från I88| har Topelius strukit det mesta av krigsskildringen, anpassat hjältinnan till en konservativare kvinnosyn, och skrivit ett förord $i$ form av ett fiktivt brev och ett svar på det, där han motiverar ändringarna.

Den version av Hertiginnan af Finland som har fătt störst spridning under 1900-talet ingår i den postuma bokhandelsupplagan Samlade skrifter som Valfrid Vasenius redigerade. Vasenius återger versionen från I88I, men utesluter Topelius förord. Med strykningen försvinner varje antydan om skillnaderna mellan Hertiginnan af Finland 1850 respektive I88I. Vasenius Hertiginnan af Finland har utkommit separat flera gånger under 1900-talet, senast i Nya klassikerserien 1994 med ett nytryck 1997. Den raderade utgivningshistorien, som Topelius inte har auktoriserat, har lett till att forskare i god tro hänvisar till Hertiginnan som utkom 1850, när de i själva verket har läst Vasenius stympade version för Samlade skrifter från $1899 .{ }^{9}$

Päivi Lappalainen har utrett textförlagorna till de finska översättningarna av Hertiginnan af Finland och visar hur kvinnobilden förändras i konservativare riktning i dem. Hon understryker att valet av version eller översättning påverkar vår uppfattning av författaren. (Lappalainen 2007: 87 ff.) ${ }^{10}$ Det står givetvis läsaren fritt att välja vilken version som helst, men forskare bör vara medvetna om skillnaderna mellan dem.

\footnotetext{
7 Zacharias Topelius, Hertiginnan av Finland och andra historiska noveller, utg. av Pia Forssell under medverkan av Matti Klinge och Anna Movall 2013. Utgåvans lästext är baserad på bokupplagan av Hertiginnan af Finland 1850. Skillnaderna mellan den och följetongen framgår av variantvisningen.

8 För utgivningshistorien och skillnaderna mellan följetongen och bokupplagan av Hertiginnan af Finland 1850 se inledningen till utgåvan och varianterna http://www. topelius.fi/index.php?p=texts\&bookld=5\#itemld=5_I \&sectionld=ch3\&columns=[[|il|,I],[|lt|,-I],[|ko|,-I],[|va|,0],[|va|, I]] I utgåvan av Vinterqvällar, planerad till 2020-talet, ingår en motsvarande jämförelse mellan de tidiga trycken och Topelius version från $\mid 88 \mathrm{I}$. 9 Hertiginnan af Finland utgör del 7 av Samlade skrifter. Vasenius återger visserligen förordet, men i en undanskymd textkritisk kommentar i del 25 , och den beaktas inte i separattrycken.

10 Hertiginnan af Finland översattes först av Tuomo Luhtanen 1874, enligt bokupplagan 1850, men utan den viktiga historiska delen. Aatto Suppanen översatte 1885 versionen i Vinterqvällar och inkluderade Topelius nya förord, men det ingår inte i de finska upplagorna från 1900-talet.
} 
Fältskärns berättelser är den historiska roman som i Finland och Sverige har påverkat en folklig historiesyn mest, före Väinö Linnas romaner och Vilhelm Mobergs utvandrarsvit. Topelius publicerade Fältskärns berättelser som följetong i Helsingfors Tidningar 185I-1866, visserligen med årslånga avbrott. Därefter utkom verket i bokform I853-1867, i flera upplagor på Bonniers förlag från I854. På 1880-talet utkom Fältskärns berättelser med överdådiga illustrationer av Carl Larsson. När Bonnier planerade denna upplaga ville Topelius se över romanen och göra en del mindre ändringar, bland annat reducerade han antalet svordomar. Man kan säga att Topelius härmed inledde den förvandling till ungdomsbok som sedan accelererade på 1900-talet, med talrika förkortningar och bearbetningar - också i serieform (Forssell 2009: |20-150). Topelius egna ändringar är inte lika genomgripande som i Hertiginnan af Finland, men även i fråga om Fältskärns berättelser ska läsaren vara medveten om att de olika upplagorna skiljer sig från varandra. Utgåvan i ZTS av Fältskärns berättelser utkommer 2018 och är baserad på den första bokupplagan. I utgåvans visning av varianter framgår skillnaderna mellan förstaupplagan, följetongen och den av Carl Larsson illustrerade upplagan samt en upplaga som Topelius korrekturläste på I870-talet.

\section{Textkritiska utgåvor för framtida forskning}

En historisk-kritisk utgåva är ett stort och långsiktigt åtagande för de engagerade forskarna, för förlaget och för finansiärerna. I Topelius fall är det ett gigantiskt uppdrag, eftersom författarskapet är så omfattande både kvantitativt och genremässigt. Efter tio år av intensivt arbete är sex delar utgivna och arbetet med åtta delar pågår. De utgivna delarna innehåller omkring 4000 sidor kommenterad text av Topelius och drygt 400 sidor inledningar." Med samma produktionstakt som nu kommer merparten av Topelius verk att vara utgivna 2025.

Avsikten med textkritiska utgåvor är att de ska aktualisera författarskapet, användas för nya översättningar och generera ny forskning. Topelius levererar material för forskning inom många discipliner: litteraturvetenskap, historia, lärdomshistoria, socialhistoria, språkhistoria - med flera. Överhuvud kommer utgåvan att fördjupa kännedomen om Topelius œuvre, mycket har nämligen aldrig tryckts om sedan det ingick i Helsingfors Tidningar: följetonger, kåserier, artiklar, bokanmälningar och nyhetsmaterial. Hans föreläsningar har använts av forskningen, men de tusentals sidorna har inte publicerats tidigare. Utgåvan av föreläsningarna kommer 2017 och reviderar uppfattningen om Topelius snäva inställning till upplysningen och Gustav III.

Topelius var oerhört produktiv. Till någon del beror det på att han kunde systematisera. Han gjorde till exempel upp ett register över innehållet i de populära Leopoldinerbreven som han kunde konsultera för att undvika upprepningar. Topelius återanvände också material. Texten till

\footnotetext{
"Texten i den enbart digitalt utgivna korrespondensen och i bildverken i stort format har omräknats till normalsidor i de tryckta böckerna. Antalet publicerade kommentarer är knappt 10000 och antalet publicerade personposter med levnadsår och kort beskrivning är ca 2500.
} 
bildverket En resa i Finland skrev han parallellt med Boken om Vårt Land i början av I870-talet. I båda tar han upp samma ämnen och använder liknande formuleringar, alltsammans hade han tidigare behandlat i Finland framställdt i teckningar på 1840-talet och i föreläsningar på 1860-talet. ${ }^{12}$

Topelius korrespondens med förlag och översättare är utgiven. ${ }^{13}$ De drygt 1000 breven blir en exposé över förlagsbranschen i Finland och i någon mån också Sverige, med många internationella utblickar. Topelius brevväxling är över huvud intressant, för hans korrespondenter är socialt och bildningsmässigt olika, med varierande språkliga färdigheter. Utgåvan av korrespondensen blir en fulltextresurs som gör det möjligt att studera språket i bruk. Breven ger inblickar i 1800-talets vardag och tidens frågor, inte minst breven från Topelius intelligenta och kloka mor som följde med händelserna både i lokalsamhället och i pressen. På sikt bidrar materialet $\mathrm{i}$ hela utgåvan $\mathrm{i}$ kombination med sökbarheten till en mera mångfacetterad uppfattning om Topelius och till nya aspekter på Finlands | 800 -tal. ${ }^{14}$

\section{Utgivna delar 2010-2015:}

Ljungblommor, utg. Carola Herberts under medverkan av Clas Zilliacus, ZTS I, SSLS 742, 2010 till den digitala utgåvan

Finland framställdt i teckningar, utg. Jens Grandell och Rainer Knapas, ZTS XII, SSLS 747, 201 I till den digitala utgåvan

Noveller, utg. Pia Forssell, ZTS IV, SSLS 770, 2012 till den digitala utgåvan

En resa i Finland, utg. Katarina Pihlflyckt, ZTS XIII, SSLS 775, 2013 till den digitala utgåvan

Hertiginnan af Finland och andra historiska noveller, utg. Pia Forssell under medverkan av Matti Klinge och Anna Movall, ZTS V, SSLS 782, 2013 till den digitala utgåvan

Zacharias Topelius korrespondens med förlag och översättare, utg. Carola Herberts, ZTS XX, 2015 till den digitala utgåvan

[till den digitala utgåvan = länk till resp. utgåva]

\section{Utkommer 2016-2018:}

Dagböcker 1832-1840

Föreläsningar 1854-1866

Naturens bok och Boken om Vårt Land

Nya blad och Ljung

Zacharias Topelius korrespondens med föräldrarna

Fältskärns berättelser

Läsning för barn

\footnotetext{
12 Se Katarina Pihlflyckts inledning till Topelius, En resa i Finland 2013 http://www.

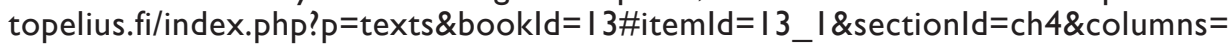
[[|il|,-I],[|lt|,-I],[|ko|,-I]]

${ }_{13}^{13}$ Zacharias Topelius korrespondens med förlag och översättare, utg. av Carola Herberts 2015 http://www.topelius.fi/index.php?p=texts\&bookld= I5\#itemld= I5_I I 08\&collectionld $=\mid$ \&columns=[[|ti|,-I],[|lt|,-I],[|ko|,-I]] Beslutet att utge förlagskorrespondensen i ett tidigt skede fattades för att dessa brev stöder arbetet med flera andra utgåvor.

14 Det redaktionella arbetet är ett teamwork. Det är också fallet med artikeln. Redaktörerna Jens Grandell, Carola Herberts, Anna Movall och Katarina Pihlflyckt samt e-redaktören Johan Kylander tackas för synpunkter och statistik.
} 


\section{KÄLLOR}

Björklund, Kim och Petra Söderlund 20I I: "Andra generationens elektroniska utgåvor - Selma Lagerlöf-arkivet och Zacharias Topelius Skrifter." I Pia Forssell och Carola Herberts (red.), Digitala och tryckta utgåvor. Erfarenheter, planering och teknik i forrändring. Skrifter utgivna av Svenska litteratursällskapet i Finland 755. Nordiskt Nätverk för Editionsfilologer, Skrifter 9. Helsingfors: Svenska litteratursällskapet i Finland.

Forssell, Pia 2009: "Fältskärns förvandlingar. Romanens väg från följetong till textkritisk utgåva.” I Mats Malm, Barbro Ståhle Sjönell och Petra Söderlund (red.), Bokens materialitet. Bokhistoria och bibliografi. Nordiskt Nätverk för Editionsfilologer, Skrifter 8. Stockholm: Svenska Vitterhetssamfundet.

Klinge, Matti 20I4: Pinaatti ja Saint-Simon: Päiväkirjastani 20/3-20/4. Helsinki: Siltala.

Lappalainen, Päivi 2007: "Zacharias Topeliuksen Hertiginnan af Finland -romaanin variantit ja niiden suomennokset." I H. K. Riikonen (päätoim.), Suomennoskirjallisuuden historia 2. SKST III2. Helsinki: Suomalaisen Kirjallisuuden Seura.

Topelius, Zacharias 20I0: Ljungblommor, utg. av Carola Herberts under medverkan av Clas Zilliacus, Zacharias Topelius Skrifter (ZTS) I, SSLS 742. Helsingfors: Svenska litteratursällskapet till den digitala utgåvan

Topelius, Zacharias 20I3: En resa i Finland, utg. av Katarina Pihlflyckt, ZTS XIII, SSLS 775. Helsingfors: Svenska litteratursällskapet till den digitala utgåvan

Topelius, Zacharias 2013: Hertiginnan av Finland och andra historiska noveller, utg. av Pia Forssell under medverkan av Matti Klinge och Anna Movall, ZTS V, SSLS 782. Helsingfors: Svenska litteratursällskapet till den digitala utgåvan

[Topelius, Zacharias] 20I5: Zacharias Topelius korrespondens med förlag och översättare, utg. av Carola Herberts, ZTS XX. Helsingfors: Svenska litteratursällskapet till den digitala utgåvan

Z.Topeliuksen juhlavuoden toimikunnan raportti - Z.Topelius jubileumsår 1998 1999: Rapport avgiven av kommittén för Z. Topelius jubileumsår, utarbetad av Raija Majamaa. Kommittébetänkande 1999:2. Helsinki: Yliopistopaino.

\section{Författare}

Pia Forssell, fil. dr, huvudredaktör och Märtha Norrback, fil. mag., redaktionschef, Svenska litteratursällskapet i Finland, Zacharias Topelius Skrifter (pia.forssell[at]sls.fi, martha.norrback[at]sls.fi) 